Vol. 6 (1997): 229-239.

\title{
Review
}

\section{Sustainability - a challenge to animal production and breeding}

\author{
Heidi Torp-Donner, Jarmo Juga \\ Department of Animal Science, FIN-00014 University of Helsinki, Finland. Current address: Finnish Animal \\ Breeding Association, PO Box 40, 01301 Vantaa, Finland, e-mail: heidi.torp@mloy.fi
}

\begin{abstract}
Prospects of sustainable animal breeding are briefly reviewed from the animal breeding point of view. The aspects of sustainability included are: ecological sustainability such as environmental sustainability and maintenance of biodiversity as well as ethical and economical sustainability. Environmental degradation can be reduced by intensive production at least on intermediate production levels. Biodiversity of livestock breeds can be maintained with globally diverse breeding goals containing several traits and with national conservation schemes for rare local breeds. Ethical sustainability can be taken into account by improving health and longevity traits. Production must also be economically profitable, otherwise it is not sustainable. In optimising all these aspects, the animal breeders have to lay down criteria for conservation programmes and re-evaluate breeding goals so that sustainability is taken into account.
\end{abstract}

Key words: biodiversity, ecological, economical, environmental sustainability, ethical, sustainable livestock production

\section{Introduction}

Sustainable livestock production means a production that is ecologically, taking into account the environment and biodiversity, ethically and economically sustainable. No concise, universally acceptable definition of sustainable agriculture has yet emerged, but most agriculturists agree that the concept of sustainable agriculture is of paramount importance to the sustainability of our biosphere and its ever-increasing human population (Heitschmidt et al. 1996).
Sustainable agricultural systems should maintain or enhance environmental quality, use non-renewable resources wisely, promote the maintenance of renewable resources including animal and plant biodiversity and promote economic viability. According to Vavra (1996) sustainable systems are those that exist in the overlap of what the current generation wants for itself and future generations and what is biologically and physically achievable in the long run.

In livestock production, sustainability could mean being able to harvest the same quantity of meat, milk or fibre from a given land base in- 


\section{AGRICULTURAL AND FOOD SCIENCE IN FINLAND}

\section{Torp-Donner, H. \& Juga, J. Sustainability - animal production and breeding}

definitely (Vavra 1996 and Heitschmidt et al. 1996). Because of the large heterogeneity of livestock production systems, a system-specific analysis is needed to evaluate all these criteria for sustainability.

Research and extension services need to provide leadership in developing alternative systems that provide the broad view of sustainability before we are painfully forced into it by restrictive legislation (Vavra 1996). An environmental programme of agriculture resulting from the regulations of the European Union has already been prepared by the Ministry of Agriculture and Forestry in Finland (The Ministry of Agriculture and Forestry 1995). The requirements listed in the programme will lead to substantial investment costs for farmers and the effects of these costs on livestock production have not been studied.

The goal of this review is to discuss the following criteria that are used to describe sustainable livestock production: 1) the environment: air, surface and groundwater quality and degradation, 2) the biodiversity of livestock, its measures and the opportunities and dangers of biotechnology, 3) the ethical aspects of livestock production that consist of human attitudes and the welfare and health of animals, and 4) the economical aspects of the three previous criteria. Animal breeding methods that could enhance sustainable livestock production are also discussed. Future research for defining and evaluating sustainability will also be suggested.

\section{Environment}

\section{Air quality}

Emissions from agriculture into the air include methane $\left(\mathrm{CH}_{4}\right)$, carbon dioxide $\left(\mathrm{CO}_{2}\right)$ and nitrous oxide $\left(\mathrm{N}_{2} \mathrm{O}\right)$, which speed up climate change, as well as ammonia $\left(\mathrm{NH}_{3}\right)$, which causes eutrophication of the soil and water. Agriculture, especially livestock production, is the main source of methane emissions in Finland (55\% of all methane emissions). Emissions from other sources are not so great (Yläranta 1991). Emission of methane, carbon dioxide and nitrous oxide can be reduced to some extent by new methods and technologies for manure and urine storage and handling.

The major cause of methane emission is, however, ruminant digestion. That emission can be diminished by reducing the number of animals and by optimising the feeding of animals. On the other hand, if food production needs to be maintained at the present level, one possible way to diminish methane emission is to increase the production efficiency per animal. Calculations show that methane emissions are reduced from $30 \mathrm{~g} / \mathrm{kg}$ of milk produced to $15 \mathrm{~g} / \mathrm{kg}$ when annual milk production is increased from $4000 \mathrm{~kg}$ of milk per animal to $8000 \mathrm{~kg}$ (Flachovsky 1994).

\section{Surface and ground water quality}

Phosphorus and other nutrient loads in surface water is a major problem in Finland because of rainy autumns and melting snow in spring. Nutrient loads in surface water cause eutrophication. Over $80 \%$ of arable land in Finland is in grass production, which prevents the nutrient load from reaching the surface water. Livestock production is thus superior to crop production from the nutrient load point of view (The Ministry of Agriculture and Forestry 1995). Nutrient load in surface water as well as in ground water can be diminished by improved cultivation methods and by increasing grass production.

Preliminary calculations show a reduction in $\mathrm{N}$-emissions from $337 \mathrm{~g} / \mathrm{kg}$ of meat produced to $231 \mathrm{~g} / \mathrm{kg}$, when the daily growth of a beef animal is increased from $800 \mathrm{~g} /$ day to $1600 \mathrm{~g} /$ day (Korhonen 1996). It is also estimated that the improvement of the production performance of animals realised in the last decade by improved breeding programmes has contributed to reduce the polluting power by, approximately $25 \%$ in swine and $30 \%$ in poultry (Matassino et al. 1991). These results suggest that increased efficiency is environmentally more sustainable than 


\section{AGRICULTURAL AND FOOD SCIENCE IN FINLAND}

Vol. 6 (1997): 229-239.

Table 1. Total $\mathrm{N}$ - and $\mathrm{P}$ - emissions ( $\mathrm{kg}$ ) per 1 million $\mathrm{kg}$ product (meat or milk) and returns (FIM per $\mathrm{kg}$ $\mathrm{N}$ - or $\mathrm{P}$ - emission) in different production levels in meat and in dairy production.

\begin{tabular}{lrrrrrr}
\hline & \multicolumn{3}{c}{ Meat production (g/day) } & \multicolumn{3}{c}{ Milk production (kg/year) } \\
& 800 & 1200 & 1600 & 4000 & 6000 & 8000 \\
\hline Return (FIM/year) & 3998 & 5998 & 7997 & 7840 & 11760 & 15680 \\
$\mathrm{~N}(\mathrm{~kg} / 1$ mill.kg prod.) & ${ }^{2)} 326300$ & 243100 & 224000 & ${ }^{3)} 20000$ & 16000 & 15000 \\
Return (FIM/N-kg) & 43 & 57 & 62 & 98 & 123 & 131 \\
$\mathrm{P}(\mathrm{kg} / 1$ mill.kg prod.) & ${ }^{2)} 66000$ & 55600 & 57300 & 3) 3000 & 2000 & 1500 \\
Return (FIM/P-kg) & 210 & 250 & 242 & 653 & 980 & 1307 \\
\hline
\end{tabular}

1) Evaluated from the basis of the mean producer prices in year 1995 paid in Finland (Maaseudun Tulevaisuus 23.3.1996).

2) Evaluated from the basis of calculations about feed costs and $\mathrm{N}$ - and $\mathrm{P}$-emissions in meat production (Korhonen 1996).

${ }^{3)}$ Evaluated from the basis of calculations made by Flachowsky 1994.

extensive goals. This is certainly the case for low and intermediate production levels, but more information about environmental efficiency is still needed for very intense production systems. A very intense beef production system, which has a heavy reliance on fossil fuels and extra protein foods to maintain a productive cow herd in regions where nutrient shortfalls are common, carries with it some ecological and economic risks (Heitschmidt et al. 1996). These risks arise from the assumption of the availability of cheap sources of exogenous energy and the potential disruption of critical life-supporting ecological systems due to continued generation of degradants (Heitschmidt et al. 1996).

In Table 1 the incomes (FIM) are evaluated per $\mathrm{kg}$ of $\mathrm{N}$ - and $\mathrm{P}$-emissions from manure and urine for dairy cows and for meat production. Dairy cows bring in twice as much money per $\mathrm{kg}$ of $\mathrm{N}$ emitted as do meat animals and the difference in P-emission is even bigger. Thus milk production could better cover the costs that arise when accounting for environmental aspects. The calculations also show that the financial incomes are proportionally higher when the production increases from a low production level to an intermediate level than from an intermediate level to a high production level. The $\mathrm{P}$-emissions produced by meat production turned out to be even higher in high production levels than in intermediate production levels.

Biologically sustainable husbandry systems for cattle and sheep can be achieved by sustainable nutrient management. This implies fine tuning of nutrient ( $\mathrm{N}, \mathrm{P}$ and $\mathrm{K}$ ) input and output to achieve and maintain agronomically desired and ecologically acceptable reserves of nutrients in the soil (Hermans and Vereijken 1994). The annual in- and output balance sheets of various nutrients at a farm or regional level should be maintained and the available soil reserves of nutrients should also be evaluated. Nutrient flows are as follows: nutrient input to an agri-environmental system comes from fertilisers, feeds and biological nutrient fixation and nutrient output contains products and manure, if transported from the farm, losses as nutrient volatilisation, run-off and leaching (Hermans and Vereijken 1994).

Selection of livestock for efficiency of feed utilisation resulted in decreased losses in the poultry meat production cycle through manure, slaughter offal and mortality. Feed costs were also reduced and the slaughter yield was equivalent or improved when compared with selection for growth rate (Leenstra and Ehlhardt 1994). These direct and correlated effects of selection of livestock on the efficiency of feed uti- 


\section{Torp-Donner, H. \& Juga, J. Sustainability - animal production and breeding}

lisation indicate good means for establishing environmentally acceptable poultry meat production. Two aspects did not favour the selection for efficiency of feed utilisation: the increased rearing period and the increased costs of the selection itself (Leenstra and Ehlhardt 1994). However, if environmental degradation is included as an extra cost, it will make the more costly selection of livestock profitable.

Another important measure of production efficiency is the efficiency of converting vegetable energy and protein into meat or milk (Oltjen and Beckett 1996). Dairy production efficiency ranges from $96 \%$ to $276 \%$ on the basis of production of humanly consumable protein. The protein resulting from ruminant livestock production is of higher quality with greater biological value than the protein in the substrate feeds (Oltjen and Beckett 1996) Thus the argument that ruminant livestock belong in sustainable livestock production is convincing.

\section{Biodiversity}

Biodiversity of all ecosystems stabilises the functions of these systems and their interactions with surrounding ecosystems. Thus, agri-ecosystems influence their surroundings and vice versa. Sustainable management of diversity in livestock production aims for the sustainable use of genetic resources and the maintenance of genetic variability for present and future needs. The Finnish agri-environmental programme pays premiums for preserving traditional biotopes and rare local breeds (The Ministry of Agriculture and Forestry 1996), which has sometimes been justified by the future needs of animal breeding, but has more to do with conserving the Finnish cultural heritage. The agri-ecosystem accounts for a small proportion of total biological diversity, but impact on human survival is of great importance. This means that agricultural biodiversity enables continuous food production for man in different environments, but has little meaning if the evolution of all ecological biodiversity is considered (Haila 1995). Specific agricultural environments around the world impose biological limitations for the production animals, and thus breeding goals for specific environments are needed, which on the other hand, enhance global biodiversity (Beilharz et al. 1993).

\section{New mutations}

Variability between and within different species and breeds is caused by evolutionary forces like mutation, natural selection, isolation, migration and random drift. In proteins, neutral mutations are more frequent than the ones which are strongly selected against. Mutations provide new variation, and thus new response in selection can be achieved. The effects of mutations are usually small or neutral, but the balance between mutations and selection the response to selection has been achieved in long-term selection programmes, as the number of mutative loci is great in quantitative traits. Mutations with large effects can cause new achievements or changes in breeding programmes (Hill 1989). Well-known examples of major genes in animal breeding are: the halothane gene in swine, the dwarf gene in poultry, the double muscling gene in cattle and the boorola gene in sheep (Mackay 1989). Many of these major genes have negative effects on viability and fertility. Mutations with negative effects on fitness are quickly eliminated. Thus variability caused by mutations is greater, the more neutral mutations are involved (Crow 1986). Nearly all mutations are lost in a few generations through random genetic drift even if they were favourable, because their frequencies are low (mutation frequency $/$ locus $/$ generation = $\left.10^{-4}-10^{-8}\right)$.

\section{Maintenance of variation in breeding populations}

Selection decreases the genetic variance in breeding populations. The loss of genetic varia- 


\section{AGRICULTURAL AND FOOD SCIENCE IN FINLAND}

Vol. 6 (1997): 229-239.

tion depends on the intensity of the selection of the parents of the next generation, the heritability, the population size and the mating design (Falconer 1989). Even the use of modern prediction methods like the animal model BLUP accelerates the reduction in genetic variation due to within-family selection (Meuwissen and Woolliams 1994b). Use of marker-assisted selection might also result in a lower long-term selection response due to reduced genetic variability (Gibson 1994).

The population size is very important in maintaining biodiversity. When population size decreases, the inbreeding rate increases as does homozygosity. The increased inbreeding rate leads to a reduction in heterozygosity and to increased homozygosity in the population, which means decreased genetic variability. Heterozygosity as a measurement of variability describes to what extent variability remains in the population (Crow 1986). Heterozygosity in one locus can be calculated as:

Het $=1-\sum_{i=1}^{m} p_{i}^{2}$,

where $p$ is the frequency of an allele in a locus and $m$ is the number of different alleles. The mean of heterozygosity in different loci indicates the genetic variability within a breed. Heterozygosity decreases in each generation by $1 / 2 \mathrm{Ne}_{\mathrm{e}}(\mathrm{N}$, $=$ effective population size) (Crow 1986). In large populations mutations balance genetic fixation, but in small populations a random increase in homozygosity is more probable. Hence breeders should ensure that the effective population size remains large in order to avoid losing variation by random drift (Dempfle 1990).

When the inbreeding rate increases, functional traits such as reproduction and fitness decrease $3-5 \%$ per $10 \%$ increase in the inbreeding coefficient (Cunningham 1995). However, the decrease in functional traits can also be due to negative genetic correlations with the traits in breeding goals. On the other hand, fitness in a population can increase by natural selection that favours more viable individuals. In the absence of correlated responses due to artificial selection, the critical population size, at which the increase in fitness due to natural selection and the decrease due to inbreeding depression are in balance is approximately: $D / 2 \sigma_{w a}$, where $D=$ the inbreeding depression with complete inbreeding and $\sigma_{w a}=$ the additive genetic variance of fitness (Meuwissen and Woolliams 1994a).

The correlations between quantitative production traits and the fitness traits affect the response to selection in the long term. If fitness is high at an optimum level of production traits, the selection for fitness will maintain variability in production traits in the long term (Hill 1989). If fitness declines due to a correlated negative response to artificial selection, then a large increase in the critical population size is needed. However if the negative response is larger than the response to natural selection, a reduction in fitness cannot be prevented. Effective population sizes that prevent a decline in fitness are usually greater than those which maximise the genetic gain of production efficiency, so the former is a more stringent restriction on effective population size (Meuwissen and Woolliams 1994a). Another requirement for population size is set by the need to reduce uncertainties in predicting the changes from the selection applied (Meuwissen and Woolliams 1994b).

The between-breed variation in quantitative traits is often overlapping, which means that the breeds are alike. Therefore it is difficult to use quantitative traits to determine exact differences between the breeding populations and hence to define criteria for conservation purposes. This means that small populations with overlapping variation could be jointly used as a breeding population with lower risk of inbreeding and better chances to compete with other breeding populations.

Since future needs cannot be predicted, the easiest way to maintain variability is to maintain pure breeds either with in situ or ex situ methods. The best way to do this is to maintain several competitive breeds in production, because ex situ maintenance and the introgression for future needs is more expensive and time consuming than the maintenance in situ (Smith 1984). 
Torp-Donner, H. \& Juga, J. Sustainability - animal production and breeding

\section{Implications to breeding programmes}

A practical question in any conservation programme is the level of diversity to be maintained. How much of the diversity has to be maintained within a country, or does global diversity between the different countries satisfy the necessary level of diversity? In addition to the potential loss of breeds, there can be a potentially high loss of genes within a breed. In cattle, for example, this has been accelerated by new techniques such as artificial insemination, including frozen semen, multiple ovulation and embryo transfer, which makes it possible to use the same animals in many countries, and new genetic evaluation methods as the animal model BLUP (Hodges 1991).

The aim in conserving local and rare breeds is complex. The importance of conservation of such breeds for future animal breeding is difficult to forecast and involves high costs compared to the possible gains. The original breeds should be maintained because of their possible special traits in production or, as for example in developing countries, the adaptation to local climate or better resistance to local diseases. More important to many countries is, however, the cultural heritage. This means that global conservation programmes will have problems in defining which conservation programmes should be financed. Hence the funding of these programmes would be more logical on a national basis and global funds should be reserved for programmes in developing countries.

Rapid changes are taking place for example in the black and white dairy cattle populations due to the impact of the North American Holstein. In the Finnish Friesian population, the proportion of Holstein genes has increased during the past ten years. In Friesian cows born in 1980, the proportion of Holstein genes was only $2 \%$, but in cows born in 1990 the proportion was $31 \%$. In Finnish Friesian bulls the proportion of Holstein genes was $26.5 \%$ and $56.8 \%$, respectively. In other Finnish dairy breeds some changes have also occurred in breed contribution, but the changes have been much smaller than in Finn- ish Friesian cattle (Lidauer, personal communication).

The management of genetic variability in Finnish dairy breeds is monitored by AI-associations freezing sperm in long-term storage. However, the conservation of genetic material is not explicitly included in the breeding programme.

The national breeding goals maintain genetic variability within a breed if the goals differ between countries. For example the use of Holstein breed has spread to many countries, but if the breeding goals are not the same, the different lines of Holstein will increase the diversity between the countries. Diverse national breeding goals which include many traits should maintain genetic diversity both globally and locally, although this has not been quantified in any research report to date.

Goddard (1992) has shown that if the genetic correlation between the breeding goals in two countries is 0.60 at most, countries tend to select different bull sires. A pilot study on Finnish Ayrshire bulls gave a correlation of 0.84 between the total merit indices in Sweden and Finland, 0.66 between Norway and Finland and 0.84 between Norway and Sweden. The Nordic countries share a preference for breeding for total economic merit which includes yield traits and functional traits. The correlations suggest that some common bull sires could be used in Nordic breeding, but that the breeding goals are far from a consensus.

The total rate of genetic gain increases considerably by increasing population size. Combining all Nordic red dairy cattle populations would increase the total recorded population size to 757800 , the total performance testing capacity to 1110 and the total number of young bulls progeny tested to 450 (Lindhé 1995) and hence improve the management of genetic resources in red breeds.

In pigs, the genetic process for reducing fat and increasing the percentage of lean meat has been rapid in many countries and has been accompanied by problems in meat quality and stress susceptibility, especially in some Landrace populations in which the halothane gene has ap- 


\section{AGRICULTURAL AND FOOD SCIENCE IN FINLAND}

Vol. 6 (1997): 229-239.

proached the frequency of 0.9 (Hodges 1991). In the Finnish swine population, the eradication of halothane gene was very effective, and the gene was culled rapidly from both Finnish pig breeds, Landrace and Yorkshire (Puonti and Schulman 1988). The animal model BLUP -evaluations have been calculated for fertility traits (Nylander and Mäntysaari 1991) and for production traits (Haltia et al. 1993), but more research is needed to achieve sustainable breeding goals. Similar selection goals for both Finnish Landrace and Finnish Yorkshire have already increased the similarity of these breeds.

\section{Ethical aspects}

\section{Human attitudes}

Ethical aspects of livestock production methods should be evaluated together with technical and economical aspects before including them in animal production. The ethical evaluation done by consumers is, however, based on attitudes and not on research facts. In a contingent evaluation research study (Siikamäki, personal communication) on the willingness of consumers to pay more for the decrease in use of pesticides in agriculture, it was concluded that consumers are willing to pay a somewhat higher price for a product to lower the use of pesticides in Finland, but they do not ask for a total ban on pesticides. In another study (Sihvonen 1993) it was concluded that consumers are ready to pay something to improve animal production from an ethical point of view. Organic products, which also have higher prices, have been selling quite well, so some consumers are acting on the basis of their attitudes. However, in the long run difficulties might arise in marketing organic products with higher prices, if their supply increases.

It is also not clear that consumers will accept genetic manipulation in food products. The ethical aspects of new breeding techniques like marker-assisted selection and gene transfer should also be included in future breeding goals. That is why optimised production, known as "Integrated Production" (El Titi et al. 1993), will probably be the future trend, when considering all aspects affecting sustainable production.

\section{The welfare and health of production animals}

Breeding methods for sustainable and healthy animals which have genetic resistance to production-related diseases should be taken into consideration more in future breeding goals, when production levels increase. Yield traits are in fact genetically negatively correlated to fertility traits (Pösö and Mäntysaari 1996b) and udder health (Pösö and Mäntysaari 1996a). New techniques of marker-assisted selection might offer possibilities for selection based on traits that affect production sustainability or production-linked disease resistance especially in traits that have low heritability.

In research concerning breeding and animal welfare, the economic influence of health and diseases should be evaluated in more detail. The economic, as well as the ethical impact of a production related-disease is always negative, so breeding goals for animal health also warrant more research in the future.

\section{Economic aspects}

\section{Costs and premiums in Finland}

Modelling sustainability economically, ecologically and ethically forces us to evaluate costs and benefits from a new perspective compared to previous production methods. The environmental and ethical aspects are very difficult to evaluate in monetary terms, but they should be taken into account in the modelling of production which optimises environmental and economical aspects in every production scheme (El Titi 


\section{AGRICULTURAL AND FOOD SCIENCE IN FINLAND}

\section{Torp-Donner, H. \& Juga, J. Sustainability - animal production and breeding}

et al. 1993). The focus should be on merging ecology and economics so as to ensure that what is economically sound in the short term is ecologically sound in the long term (Heitschmidt et al. 1996).

In the Finnish agri-environmental programme the costs of environmental protection are evaluated and premiums are paid to farmers according to those evaluations. The premiums for livestock production that are paid at the moment are for: organic production, riparian zones, treatment of run-off waters from arable land, balanced use of manure nutrients, landscape and biodiversity management, extensive production and production based on local breeds (The Ministry of Agriculture and Forestry 1995).

\section{Costs of sustainable breeding strategies}

The conservation of genetic material generates extra costs, but the possible returns may also be large. Unfortunately the returns are hard to quantify because future needs and conditions cannot be predicted. Some principles in conservation are: to store small samples of many stocks, to choose diverse stocks, to store stocks with special traits and to store locally adapted breeds (Smith 1984). However, continuous genetic improvement in current stocks may make it increasingly difficult for unimproved conserved stocks to compete, unless there are reversals in breeding goals or drastic changes in husbandry practices (Smith 1984). The expected benefit $(B)$ in any year might be expressed by the equation: $B$ $=P\left(R-R_{0}\right)-n C$, where $P$ is the probability that one of the conserved stocks has a performance greater than the original stock and so has an economic return $R$ which is higher than the return $R_{0}$ from the original stocks, and $n$ stocks are stored, each at cost $C$ (Smith 1984). With many stocks stored, the probability of getting one stock with better performance than the original is increased. However, the above equation does not include the costs of introgression and testing the new genes or animals. Those costs might become substantial especially if there is only one gene wanted from the conserved stock, which also could be probable (Groen and Smith 1995). The costs of gene transfer and testing are at present high, so the benefit should also be very large (Smith 1984).

Very long-term support programmes, particularly at high discount rates, require an enormous ultimate pay off if the costs are to be recovered (Cunningham 1995). However, the normal horizon for such programmes is similar to a human generation, and discount rates of under $5 \%$ are commonly applied in cases like this. As a rough guide, one could say that an expected benefit of 100-200 times the annual cost could repay a 50year investment in the conservation of a breed (Cunningham 1995). The probability of a beneficial characteristic being found in the future from a gene bank population is very small.

\section{Indicators of sustainability}

\section{Proposals for implementation}

Heinonen (1995) proposed modelling for sustainable agriculture in an index form. This index aims to combine all the aspects that influence sustainability of agriculture systems and contains eight main indicators, all of which contain several variables. It is built to have values from 0 to 10 , where 10 describes a wholly sustainable production system. The indicators are: 1) Human (the enjoyability of work); 2) Dependence on outside energy (fertilisers, etc.); 3) Environmental effects; 4) Economics; 5) Biological efficiency; 6) Animal (need, etc.); 7) Social aspects; 8) Soil (erosion, etc.) (Heinonen 1995). This kind of model cannot be used in divergent production systems as the principles are quite general, but the main idea could be applied to divergent livestock production systems although more research for the modelling is needed.

In another research paper about the possibilities of modelling sustainability, the criteria were derived from explicit but complex issues of un- 


\section{AGRICULTURAL AND FOOD SCIENCE IN FINLAND}

Vol. 6 (1997): 229-239.

sustainability (de Wit et al. 1995), which resulted in the conclusion that a system-specific analysis is needed to assess the overall effect of livestock inclusion in an agricultural system on each of the proposed general criteria for sustainability. The criteria of unsustainability in that research were defined as: land scarcity, soil degradation, inefficient use of resources, environmental degradation and declining biodiversity (de Wit et al. 1995). The criteria were quite general, and from these criteria it is a long way to developing practical measurements of sustainability of livestock production.

\section{Discussion}

The environmental effects of breeding programmes are of great importance for future livestock production. If food production is to be maintained at the present level, it is unwise to decrease the intensity of production, when the increased number of animals would thus produce more negative environmental effects. At least at intermediate levels, more intense production decreases degradation. However, it is not clear how much of the degradation, such as methane emissions, does not recycle naturally into grass and crop production for livestock food. Nor is it obvious that increased intensification will reduce environmental problems at very intense levels. The interactions between divergent environments, management systems and intensity levels and production traits should be evaluated to find a sustainable way of animal production.

The traits that affect the longevity of animals, like viability, health, genetic resistance and fertility, have lower heritability than do production traits, and thus genetic progress in those traits is not as easy to attain with traditional breeding methods. However, these traits are of great importance in ethical livestock production and their impact on economics is often ignored. In big European livestock production countries, these traits are not included in the breeding goals as they are in Nordic countries. Alternative breeding programmes (e.g. MOET), the use of new techniques like marker-assisted selection and biotechnological methods like gene transfer should be studied, to discover how they enhance achievements in breeding, especially for traits that have low heritability, and how they can increase the competitiveness of different breeding populations and hence maintain genetic diversity. Although it is not clear that consumers will accept genetic manipulation in food products, the ethical aspect should be studied all the same time.

Genetically variable populations are more capable of adapting to in new situations than populations that have been developed for very narrow breeding goals. Therefore the genetic diversity of production animals should be evaluated on a national basis as well as on a global basis. The breeding goals for each breed should be evaluated considering the special traits that should be maintained and used in production. Also the effects of breeding programmes on genetic diversity should be evaluated both nationally and globally. The possible costs and benefits due to gene conservation programmes and introgression should be taken in account when planning breeding and conservation programmes. Finally, a criteria on which breed conservation is based should be laid down.

Acknowledgements. We are grateful to Esa Mäntysaari, the editor of Agricultural and Food Science in Finland, professor Kalle Maijala, the staff at the Agricultural University of Norway and two referees for their useful comments. 


\section{Torp-Donner, H. \& Juga, J. Sustainability - animal production and breeding}

\section{References}

Beilharz, R., Luxford, B. \& Wilkinson J. 1993. Quantitative genetics and evolution: Is our understanding of genetics sufficient to explain evolution? Journal of Animal Breeding and Genetics 110/3: 161-170.

Crow, J.F. 1986. Basic concepts in population, quantitative, and evolutionary genetics. W.H. Freeman and company, New York. 273 p.

Cunningham, P. 1995. Genetics, origin and conservation of domestic bovids. 35 p. (Mimeogr. available at Department of Genetics, Trinity College, Dublin 2, Ireland).

Dempfle, L. 1990. Conservation, creation, and utilization of genetic variation. Journal of Animal Science 73: 2593-2600.

El Titi, A., Boller, E.F. \& Gendrier, J.P. 1993. Integrated Production. Principles and Technical Guidelines. IOBCMPRS Bulletin 16, 1: 1-38.

Falconer, D.S. 1989. Introduction to quantitative genetics. Fourth edition, Longman Scientific \& Technical, USA. 464 p.

Flachovsky, G. 1994. Sind unsere Milchkühe "Umweltsünder"? Milchrind. Journal für Züchtung, Biotechnologie und Leistungsprüfung 4/94: 12-15.

Gibson, J.P. 1994. Short-term gain at the expence of long term response with selection of identified loci. In: Proceedings of the 5th WGALP. Vol. 21. p. 201-204.

Goddard, M. 1992. Optimal effective population size for the global population of black and white dairy cattle. Journal of Dairy Science 75: 2902-291.

Groen, A.F. \& Smith, C. 1995. A stochastic simulation study of the efficiency of marker-assisted introgression in livestock. Journal of Animal Breeding and Genetics 12/95: 161-170.

Haila, Y. 1995. Biodiversiteetti ja luonnonsuojelu. In: Hiedanpăă, J. (ed.) Biodiversity and production. Satakunnan ympäristön tutkimuskeskus \& Porin koulutus- ja tutkimuskeskus. p. 27- 40 .

Haltia, S. \& Măntysaari, E. 1993. Elăinmalli on tulossa kantakoeindeksien laskentaan. Sika 4/95: 5.

Heinonen, E. 1995. Kestävän kehityksen mukainen maataloustuotanto Suomessa. Maa-ja Metsătalousministeriö, Luonnonvaraneuvosto. MMM:n julkaisuja 3/1995. 54 p.

Heitschmidt, R.K., Short, R.E. \& Grings, E.E. 1996. Ecosystems, sustainability, and animal agriculture. Journal of Animal Science 74: 1395-1404.

Hermans, C.M.L. \& Vereijken, P.H. 1994. Grazing husbandry based on sustainable nutrient management. In: Biological basis of sustainable animal production. EAAP Publication No. 67. p. 113-122.

Hill, W. 1989. Mutation and maintenance of quantitative genetic variation. In: Hill, W. \& Mackay, T.F.C. (eds.). Evolution and Animal Breeding. Reviews on molecular and quantitative approaches in honour of Alan Robertson. C.A.B. International. p. 105-111.

Hodges, J. 1991. Sustainable development of animal genetic resources. World review of animal zootechnie. Animal Genetic Resources 3/91. p. 2-10.
Kimura, M. 1989. Neutral theory. In: Hill, W. \& Mackay, T.F.C. (eds.). Evolution and animal breeding. Reviews on molecular and quantitative approaches in honour of Alan Robertson. C.A.B. International. p. 13-16.

Korhonen, T. 1996. Tuotosjalostus tukee kestävää kehitystä. Nauta 3/96. p. 26-27.

Leenstra, F.R. \& Ehlhardt, D.A. 1994. Breeding goals for intensive but sustainable poultry meat production. In: Biological basis of sustainable animal production. EAAP Publication No. 67. p. 169-175.

Lindhé, B. 1995. Volvo-Qualităt in Skandinaviens Ställen. Tierzüchter 4/95. p. 30-33.

Mackay, T. 1989. Mutation and the origin of quantitative variation. In: Hill, W. \& Mackay, F. (eds.). Evolution and Animal Breeding. Reviews on molecular and quantitative approaches in honour of Alan Robertson. C.A.B. International. p. 111-119.

Matassino, D., Zucchi, G. \& di Berardino, D. 1991. Management of consumption, demand, supply and exchanges. EAAP Publication No. 48: 105-126.

Meuwissen, J. \& Woolliams, J. 1994a. Effective sizes of livestock populations to prevent a decline in fitness. Theoretical and Applied Genetics 89: 1019-1026.

- \& Woolliams, J. 1994b. Response versus risk in breeding schemes. Proceedings of the 5th World Congress on Genetics Applied to Livestock Production. Guelph, Ontario, Canada. Vol. 18, p. 236-243.

The Ministry of Agriculture and Forestry 1995. The agrienvironmental programme for Finland. MMM 17.2.1995, updated in 20.10.1995. $42 \mathrm{p}$.

- 1996. Uusiutuvat luonnonvarat ja biologinen monimuotoisuus. MMM:n biodiversiteettityöryhmän ehdotus monimuotoisuuden kestävăstā kăytōstă. Tyōryhmămuistio 1/1996. 79 p.

Nylander, A. \& Mäntysaari, E. 1991. Valtakunnalliset arvostelut eläinmallilla. Sika 2/91. p.8.

Oltjen, W. \& Beckett, L. 1996. Role of ruminant livestock in sustainable agricultural systems. Journal of Animal Science 74: 1406-1409.

Pősö, J. \& Mäntysaari, E. 1996a. Relationships between clinical mastitis, somatic cell score, and production for the first three lactations of Finnish Ayrshire. Journal of Dairy Science 79: 1284- 1291.

- \& Măntysaari, E. 1996b. Genetic relationships between reproductive disorders, operational days open and milk yield. Livestock Production Science 79: 4148.

Puonti, M. \& Schulman, A. 1988. Eradication of halothane gene from Finnish pig population. In: VI World conference on animal production, Helsinki. p. 478.

Sihvonen, T. 1993. Kotieläintuotteiden ja -tuotannon eettisyys taloudellisena tekijänä. Maatalouspolitiikan pro gradu -tyō. Helsingin yliopiston taloustieteen laitos. $80 \mathrm{p}$.

Smith, C. 1984. Genetic aspects of conservation in farm livestock. Livestock Production Science 11: 37-48.

Vavra, M. 1996. Sustainability of animal production systems: an ecological perspective. Journal of Animal 
Vol. 6 (1997): 229-239.

Science 74: 1418-1423.

Wit, J. de, Oldenbrock, J.K., van Keulen, H. \& Zwart, D. 1995. Criteria for sustainable livestock production: a proposal for implementation. Agriculture, Ecosystems \& Environment 53: 219-229.
Yläranta, T. 1991. Maataloustuotannon vaikutus kasvihuoneilmiőon Suomessa. Kasvihuonekaasupăăstöjen văhentäminen. Maatalouden tutkimuskeskus, Tiedote 5/1991. 18 p.

\title{
SELOSTUS
}

\section{Kestävän kehityksen vaatimukset kotieläintuotannossa ja -jalostuksessa}

\author{
Heidi Torp-Donner ja Jarmo Juga \\ Helsingin yliopisto
}

Kestävän maataloustuotannon tavoitteena on käyttää luonnonvaroja taloudellisesti, yhteiskunnallisesti ja ekologisesti kestävällä tavalla. Kestävä käyttö ei kuluta pääomaa, vaan luonnonvarojen uusiutumiskyky säilyy ja niiden määrä pysyy vähintään entisen suuruisena. Luonnon elinkykyä ylläpitää myös lajien sisäinen ja niiden välinen monimuotoisuus eli geneettinen diversiteetti. Biodiversiteetin säilyttäminen takaa myös ekosysteemien monimuotoisuuden, mikä edellyttää monenlaisten kasvu- ja elinpaikkojen olemassaoloa. Tämä kirjallisuuskatsaus perehtyy kotieläintuotannon ja kotieläinten jalostuksen vaikutuksiin ja mahdollisuuksiin kestävän kehityksen turvaamisessa. Lisätutkimusta tarvitaan optimoitujen jalostusohjelmien löytämiseksi, sillä tuotannon intensiteetin nousu/eläinyksikkö keskinkertaisilla tuotostasoilla vähentää ympäristöhaittoja, mutta tuotantointensiseetin edelleen noustessa ei ympäristöhaittojen väheneminen enää olekaan selvää. Oikea painotus kestävyyden, eettisten arvojen, taloudellisuuden ja tuotantoominaisuuksien välillä on löydettävä.

Kaikkia jalostuskohteita ei biodiversiteetin takia kannata ottaa yhteen jalostusohjelmaan, vaan erikoisominaisuuksien säilyttämisen taloudellinen arvo eri roduilla on arvioitava. Kestävyyden, tuotantosairauksien ja geneettisen resistenssin periytymisasteet tulee määrittää, jotta voidaan löytää edistymisen kannalta tarkoituksenmukaiset painotukset. Lisäksi uu- sien tekniikoiden, kuten alkionsiirron, geenisiirron ja markkeriavusteisen valinnan käyttöä jalostuksen edistäjinä ja monimuotoisuuden ylläpitäjinä varsinkin heikosti periytyvissä terveys-, hedelmällisyys- ja resistenssiominaisuuksissa on mahdollisuuksien mukaan tehostettava.

Eri ominaisuuksien vuorovaikutukset eri ruokintamuotojen, tuotantoympäristöjen ja olosuhteiden kanssa vaihtelevat ja järkevä yhdistelmä saattaa olla hyvinkin erilainen eri maissa. Juuri tähän erilaistumiseen pohjautuu jalostuspopulaatioiden maailmanlaajuinen vaihtelu. Kukin tuotantoeläinlaji ja -systeemi on mallitettava eri pääkohdat huomioon ottaen. Geenipankkitoiminnan ja säilytettyjen geenien käyttöönoton todelliset taloudelliset kustannukset ja hyödyt vaihtelevat suuresti säilytettävän rodun erikoisominaisuuksien taloudellisten käyttö- ja kulttuuriarvojen mukaan. Kansallisten jalostustavoitteiden vaikutus perinnölliseen muunteluun maailmanlaajuisesti juuri erikoistumalla on merkittävää ja erilaisilla jalostusohjelmilla on mahdollisuuksia säilyttää useampi jalostuspopulaatio kilpailukykyisenä.

Tuotannon kokonaisvaltainen mallittaminen eri aloilla tulee olemaan ehto kestävälle kehitykselle. Jalostuksen sopeuttaminen kestävän kehityksen vaatimuksiin ei ole ristiriidassa nykyisen linjan kanssa, vaan kyse on järkevästi toteutettavasta optimointiprosessista. 